\title{
Vulnerability, Arctic Indigenous Groups and Oil Spills
}

\author{
Potential Contributions to the Work of the Arctic Council
}

Giovanna Maria Frisso*

The Arctic Council (AC) has been praised for recognising 'the complementarity of science and traditional knowledge to generate new knowledge and inform decision making and policy development'. Within the AC, the consideration of indigenous traditional knowledge (hereinafter, traditional knowledge) seems to have been enabled by its constitutive instrument. According to the Declaration on the Establishment of the Arctic Council, the main objective of the AC is to 'provide a means for promoting cooperation, coordination and interaction among the Arctic States, with the involvement of the Arctic indigenous communities and other Arctic inhabitants on common Arctic issues. ${ }^{2}$ The participation of indigenous groups in the AC is further promoted through the category of permanent participants, which encompasses the Inuit Circumpolar Conference, the Saami Council and the Association of Indigenous Minorities of the North, Siberia and the Far East of the Russian Federation. ${ }^{3}$ As Koivurova and Heinämäki have noted, permanent participants have been given an unprecedented status in the $\mathrm{AC}$, as they negotiate at the same table with Arctic states and may table proposals for decision. ${ }^{4}$

In the field of international disaster law, the impetus for taking into account traditional knowledge has been related to the influence of the vulnerability paradigm. ${ }^{5}$ Bearer of a strong political agenda amidst postcolonial thought,

* Lecturer at the University of Lincoln, Law School.

** I would like to thank the anonymous reviewers as well as Elizabeth Kirk, Gabriel Lopes Porras, Max Brookman-Byrne, Nicolas Kang-Riou and Richard Barns for their careful reading of the manuscript and suggestions. All the feedback received is appreciated, as it has helped improve the article.

1 David Romero Marique et al, 'Climate-related displacements of coastal communities in the Arctic: Engaging traditional knowledge in adaptation strategies and policies' (2018) 85 Environmental Science and Policy 95.

2 Declaration on the Establishment of the Arctic Council, 19 September 1996, art. 1(1).

3 Ibid, art. 2.

4 Timo Koivurova and Leena Heinämäki, 'The participation of indigenous peoples in international norm-making in the Arctic' (2006) 42/2 Polar Record 101.

5 J.C. Gaillard, 'Disaster studies inside out' (2019) 43 Disasters 7.

(C) GIOVANNA MARIA FRISSO, 2022 | DOI:10.1163/26662531_00301_014

This is an open access chapter distributed under the terms of the GC BY-NC 4.Policense. 
the vulnerability paradigm situated disasters within a broader context of (historical) unequal distribution of power and resources. ${ }^{6}$ The understanding of how people perceive and respond to hazards given their belief systems, priorities, and the resources at their disposal has become as important as harnessing local expertise to disaster risk reduction (DRR) and response. ${ }^{7}$ As such, the Yokohama Strategy and Plan of Action for a Safer World, the Hyogo Framework for Action (2005-2015), and the Sendai Framework for Disaster Risk Reduction (2015-2030) have all, albeit to different degrees, acknowledged the importance of involving local communities to DRR. ${ }^{8}$ In fact, the latter makes clear reference to 'the direct incorporation of indigenous perspectives in DRR strategies'.

Based on the role of permanent participants in the AC and the support for the incorporation of traditional knowledge in DRR ${ }^{10}$ this article examines the extent to which the different ways of living, perceiving the world and appropriating the nature reflected in the traditional knowledge of indigenous groups have been replicated in the measures aimed at reducing the risks of oil spills in the Arctic and their harmful consequences. The focus on DRR is particularly relevant due to the challenges that the Arctic weather and remoteness present to oil recovery as well as the lower rate of oil biodegradation in cold temperatures. ${ }^{11}$ The danger of oil fouling the feathers or fur of wildlife species,

$6 \quad$ Ibid.

7 Arielle T. de la Poterie and Marie-Ange Baudoin, 'From Yokohama to Sendai: Approaches to Participation in International Disaster Risk Reduction Frameworks' (2015) 6 International Journal of Disaster Risk Science 128.

Ibid.

9 Simon J. Lambert and John C. Scott, 'International Disaster Risk Reduction Strategies and Indigenous Peoples' (2019) 10(2) The International Indigenous Policy Journal 5. Lambert and Scott's assertion relies on Sections 24(i) and $36(\mathrm{a})(\mathrm{v})$ of the Sendai Framework. Section $24(\mathrm{i})$ states that to understand disaster risk at national and local levels it is necessary 'to ensure the use of traditional, indigenous and local knowledge and practices, as appropriate, to complement scientific knowledge in disaster risk assessment and the development and implementation of policies, strategies, plans and programmes of specific sectors, with a cross-sectoral approach, which should be tailored to localities and to the context'. Section $36(\mathrm{a})(\mathrm{v})$, concerning the role of stakeholders, reads: 'indigenous peoples, through their experience and traditional knowledge, provide an important contribution to the development and implementation of plans and mechanisms, including for early warning'.

10 See UN General Assembly, Promotion and protection of the rights of indigenous peoples in disaster risk reduction, prevention and preparedness initiatives, Study by the Expert Mechanism on the Rights of Indigenous Peoples, Annex, (7 August 2014) UN Doc A/HRc/27/66.

11 See Daria Shapovalova, 'Special rules for the Arctic? The analysis of Arctic-Specific Safety and Environmental Regulation of Offshore Petroleum Development in the Arctic Ocean States' in Eva Pongrácz et al (eds) Arctic Marine Sustainability (Springer 2020) 275. 
which depend on them for insulation, as well as the longer lifespans and slower generational turnover of some species 'exacerbate the potentially negative consequences of an oil spill. ${ }^{12}$ As many Arctic indigenous communities depend on clean land and waters for subsistence, oil spills can result in a significant level of physical, social and economic disruption.

Grounding, collision, ice or heavy weather damage, machinery damage or failure are some of the circumstances that could lead to the unintended release of oil by vessels in the Arctic. ${ }^{13}$ Oil pollution has also been related to offshore oil developments. ${ }^{14}$ The most recent materialisation of an oil spill took place on 29 May 2020, in the northernmost city in the world, Norilsk, when an oil-storage tank collapsed and consequently spewed more than a hundred and fifty thousand barrels of diesel fuel into the Ambarnaya River. The largest spill to ever occur in the Russian Arctic led President Vladimir Putin to declare a state of emergency. ${ }^{15}$ Interviewed by Vikulova, Grigory Dyukarev, the Chair of the Association of Indigenous Minorities of the Taimyr Krasnoyarsk Territory, explained that:

This accident is devastating to our economy. The river is spawning, and our people go fishing there. In general, the river feeds us. It is [...] like a supermarket for you. In the city you can go to the store, but we live in a tundra. And if the river is polluted: there will be no more fish for us. But we will lose not only fish: a wild deer is likely to change migration routes, so we will have to travel hundreds of kilometres for hunting. ${ }^{16}$

wWF, 'Oil Spill Response Challenges in Arctic Waters' (wWF 2007) $7<$ http://assets.panda .org/downloads/nuka_oil_spill_response_report_final_jan_o8.pdf> last accessed (as any subsequent URL) on 19 July 2021.

13 See Marchenko et al, 'Arctic Shipping and Risks: Emergency Categories and Response Capacities' (2018) 12/1 International Journal on Marine Navigation and Safety of Sea Transportation 113. 'Beyond major oil spills there are several chronic exposures: natural seepage, leaking pipelines, tanker harbour spills, tanker discharges from cleaning, and aerial contamination from internal combustion engines'. Zoey Walden and Jon Rozhon, 'Oil Spills and First Nations: Exploring Environmental and Land Issues Surrounding the Northern Gateway Pipeline' (Canadian Energy Research Institute 2012) $6<$ https://ceri.ca/ assets/files/Study_129_Part_IV_Full_Report.pdf>.

14 See Shapovalova (n 11) and wwF (n 12).

15 в вС, 'Arctic circle oil spill prompt Putin to declare state of emergency', в вс News (London, 4 June 2020) <https://www.bbc.co.uk/news/world-europe-52915807\#: :text=Russia's\%2O President\%2oVladimir\%2oPutin\%2ohas,river\%2owithin\%2othe\%2oArctic\%2oCircle .\&text=Arctic\%2opermafrost $\% 2$ ohas\%2obeen\%2omelting,for\%2othis\%2otime\%2o of\%2oyear $>$.

16 Olesia Vikulova, 'The human cost of oil: how indigenous and ethnic minorities bear the brunt of disasters' (Greenpeace International, 26 June 2020) <https://www.green 
The increasing risk of major pollution accidents in the Arctic has been associated with climate change. The melting ice furthers shipping activity in the Arctic as well as offshore energy developments. ${ }^{17}$ Besides that, the loss of permafrost due to climate warming puts at risk of collapse the infrastructure of various cities. The melting permafrost was, indeed, pointed out as the cause of the Nornickel oil spill. ${ }^{18}$ It is within this complex context, which involves climate change, that this article examines whether traditional knowledge has been incorporated in DRR measures adopted by the Emergency Prevention, Preparedness and Response Working Group (EPPR) of the AC to reduce the risks of oil spills and their consequences in the Arctic. ${ }^{19}$

EPPR has been defined as a forum in which member governments and indigenous peoples work to better prevent, prepare for and respond to environmental threats from accidental discharges of pollution from activities which take place in the Arctic'. ${ }^{20}$ As such, the majority of its work has been 'directed at assessing threats to the Arctic environment which could result in the need for emergency response measures, and at facilitating the improved ability to

peace.org/international/story/43820/human-cost-oil-indigenous-ethnic-minorities -brunt-of-disasters/>.

17 See Paul M. Suprenand et al, 'Ecological and Indigenous community Impacts of Oil Spill Mortality in Alaskan Marine Ecosystems' (2018) Marine Science Faculty Publications 26o.

18 Various news outlets related the oil spill to the melting permafrost. See, for instance, В BC, 'Arctic Circle oil spill: Russian prosecutors order checks at permafrost sites' (ввс News: 5 June 2020) <https://www.bbc.co.uk/news/world-europe-52941845> and Elizabeth Weise et al., 'Russia Declares states of emergency over Arctic Circle oil spill caused by melting permafrost' (USA today: 5 Jun 2020) <https://eu.usatoday.com/in-depth/graphics/2020/ o6/o5/oil-spill-red-river-permafrost-tied-russian-arctic-circle-emergency-diesel/ $3143679001 />$. Nonetheless, in this case the oil spill has caused by the overall failure of the company to investigate potential warning signs in the years leading up to the disaster. See: Independent Environmental Advisory Support to the Nornickel Environmental Task Team, 'Review of May 2020 Catastrophic Tank Failure, HPP-3, Norilsk', 25 November 2020 <https://www.nornickel.com/files/en/media-library/presentation/erm -1a-report-for-nornickel-ett-public-issued-25-11-2o-en.pdf $>$.

19 Other AC working groups contribute to the prevention of oil pollution. See, Arctic Council Secretariat, 'Framework Plan for Cooperation on Prevention of Oil Pollution from Petroleum and Maritime Activities in the Marine Areas of the Arctic' (2017) <https:// oaarchive.arctic-council.org/bitstream/handle/11374/1938/2017-05-O5-EPPR-Report _Implementation_Framework_Plan_OPP-Edocs-3742.pdf?sequence $=1 \&$ isAllowed $=y>$. It is also important to note that AC working groups collaborate with other international organisations. Acting within the International Maritime Organization, for instance, E P PR contributed, among others, to the project on in situ burn of oil spills on water and broken and solid ice conditions for the Arctic region, the draft guide entitled Oil-Spill Response in Ice and Snow and the development of a manual on oil spill response in ice and snow conditions.

Edward H. Owens et al, 'Field Guide for Oil Spill Response in Arctic Waters' (AC 1998) ii. 
prevent or mitigate these threats'.21 In case of oil spills, risk assessment needs to take into account, among others, the location and timing of the spill, ice and weather conditions, the behaviour of oil, the distribution and abundance of species in the affected area, their vulnerability and sensitivity to oil as well as the inherent limitations of the spill response. ${ }^{22}$

This article will analyse the incorporation of traditional knowledge in the efforts to assess the risks posed by oil spills and, consequently, to the development and implementation of DRR measures by the EPPR through a review of the literature. In this context, general references to traditional knowledge are not intended to essentialise a complex group. ${ }^{23}$ On the contrary, by bringing to the fore the debates related to vulnerability in international disaster law, the article draws attention to the need for a more contextualised understanding of the risks posed by oil spills. The originality of the article lies, therefore, on the understanding that DRR requires a more comprehensive engagement with traditional knowledge in the Arctic, one that encompasses not only the economic, geographical, and historical particularities of each region but also the relatedness of indigenous groups to the land. Engagement with the traditional knowledge of the various indigenous communities living in the Arctic is necessary for a more complete and richer assessment of the risks posed by oil spills.

To develop this argument, the first section of the article draws from the literature on vulnerability to situate the potential contribution of traditional knowledge to DRR. It argues that the literature on vulnerability within international disaster law focuses on setting thresholds to inform action, ${ }^{24}$ resulting in a limited understanding of vulnerability. As such, the potential contribution

\section{Ibid.}

22 CEARCTIC and CEPOLAR, 'Oil Spill Risk Analysis in the Arctic' (Environmental and Ecological Statistics, 3 February 2021) <https://www2.helsinki.fi/en/researchgroups/environ mental-and-ecological-statistics/oil-spill-risk-analysis-in-the-arctic > and PEW Environmental Group, 'Oil spill prevention and response in the US Arctic Ocean: unexamined risks, unacceptable consequences' (November 2010) <https://www.pewtrusts.org/ / media/legacy/oceans_north_legacy/page_attachments/oil-spill-prevention.pdf>.

23 From a technical perspective, this complexity is illustrated by the fact that 'it is even difficult to establish how many indigenous people there are in a given space and time since (in the Arctic) the question of who counts as indigenous and on which grounds is all but straightforward. Different jurisdictions have different answers for this: some use blood relation, some self-identification, some place of birth, and again other's geographical location and group size. (...) Further, some censuses do not differentiate between different indigenous groups, e.g. between American Indians and Alaska Natives, and some do not register ethnicity in their official statistics at all'. Kathrin Stephen, 'Societal Impacts of a Rapidly Changing Arctic' (2018) 4 Current Climate Change Reports 228.

24 Ronald W. Perry, 'What is a disaster?' in Havidan Rodriguez et al (eds), Handbook of Disaster Research (Springer 2017) 1. 
of traditional knowledge to DRR is also limited. Through the analysis of the measures adopted by the EPPR, the second section of the article highlights that, even within a limited framework, the ways of living and perceiving the world of indigenous peoples have not been fully considered when addressing the risks posed by oil spills in the Arctic. Exploring this missed opportunity, the article suggests that further engagement with indigenous communities and their knowledge enables a more comprehensive identification and assessment of the risks posed by oil spills in the Arctic and, therefore, a more successful DRR approach.

\section{Traditional Knowledge and Vulnerability}

'Human life is conditioned by vulnerability'. ${ }^{25}$ By virtue of our embodiment, human beings have bodily and material needs; are exposed to physical illness, injury, disability, and death. ${ }^{26}$ Nonetheless, vulnerability is also relational, situational. ${ }^{27}$ Although everyone is potentially vulnerable, inequalities of power, dependency, capacity or need render some more vulnerable to harm than others. ${ }^{28}$ The relational understanding of vulnerability has been particularly important to the development of international disaster law. It has highlighted that disasters are not caused solely by natural, environmental forces, they emerge from interactions between humans and the environment. The overall consequences of hazards and our ability to address them are mediated by the social context.

The understanding of vulnerability from a relational perspective requires the debates on international disaster law to focus on a particular (local) humanenvironment system and its ability to adapt, mitigate, or otherwise interact with hazards. The analysis of the local, nonetheless, demands the exploration of a broader relational framework, bringing to attention power relationships between local, national, and international levels. These power relationships are also situated within a temporal spectrum, requiring the consideration of the root causes of disasters and their long-term impact. In this perspective, societal disrespect for, and ignorance about, the environment and the lack of

25 Catriona Mackenzie et al, 'Introduction: What is vulnerability, and why does it matter for moral theory?' in Catriona Mackenzie et al (eds), Vulnerability: New Essays in Ethics and Feminist Philosophy (OUP 2014) 1.

26 Martha A. Fineman, 'Vulnerability and Inevitable Inequality' (2017) 4/3 Oslo Law Review 145 .

27 Mackenzie (n 25) 7 .

28 Ibid, 6. 
'mutuality in the relationship'29 between humans and the environment as well as among humans themselves becomes central.

Within this approach, traditional knowledge becomes relevant due to its origin in the relationship between a community and a unique natural environment. It has the political potential to bring forward other ways of understanding and framing this relationship. This potential is illustrated in the definition of traditional knowledge offered by Batiste and Henderson:

[...] knowledge is the expression of the vibrant relationships between people, their ecosystems, and other living beings and spirits that share their lands. [...] All aspects of knowledge are interrelated and cannot be separated from the traditional territories of the people concerned. [...] To the indigenous ways of knowledge, the self exists within a world that is subject to flux..$^{30}$

In this perspective, indigenous peoples' responses and approaches to natural hazards are part of their daily relationships with nature in a specific location. ${ }^{31}$ Indigenous peoples' experiences in highly at-risk areas have allowed them to develop practices to prepare for, cope with and survive disasters for millennia. In practical terms, traditional knowledge includes an understanding of society-nature relationships that have been tested by time and proven to be sustainable and successful in predicting hazards and limiting their effects. 'Indigenous groups have learned to read the signs in nature - the sea, the rain, the ice, the wind, clouds, vegetation and wildlife - to predict natural hazards. Direct (long-term) experience with natural hazards has taught many indigenous groups the duration, location, time, frequency, intensity, and predictability of these events, ${ }^{32}$ allowing them to limit their effects.

These signs are interpreted within a different worldview. As explained by Mc Gregor, '(t)he "natural world”, "environment”, or "Creation" are essential parts

29 Thérèse O'Donnell, 'Vulnerability and the International Law Commission's Draft Articles on the Protection of Persons in the Event of Disasters' (2019) 68/3 International \& Comparative Law Quarterly 604.

30 Deborah Mc Gregor, 'Coming full circle: indigenous knowledge, environment, and our future' (2004) $28 / 3 \& 4$ American Indian Quarterly 39o.

31 Marjorie Balay-As et al, 'Deconstructing the binary between indigenous and scientific knowledge in disaster risk reduction: Approaches to high impact weather hazards' (2018) 30 International Journal of Disaster Risk Reduction 18.

32 Economic and Social Council, 'Study on engaging indigenous peoples more inclusively in the disaster risk reduction process' (2O February 2013) UN Doc E/V.19/2013/14, paras 44 and 45 . 
of indigenous knowledge. Indigenous knowledge is not just "knowledge" per se. It is the lives lived by people and their particular relationship with Creation.' ${ }^{33}$ We are talking about knowledge with differing logic and epistemology from that of scientific knowledge. ${ }^{34}$ Taking this into account, the Inuit Circumpolar Council stated that 'while the two sources of knowledge (traditional knowledge and scientific knowledge) may complement each other in many cases, they are not the same and should be appreciated for what each is able to bring to the table. ${ }^{35}$ It is, therefore, important not to attempt to translate one source of knowledge into the other. ${ }^{36}$

Nonetheless, the possible integration of such worldviews in policies concerning disasters has been significantly reduced considering the instrumentalisation of the notion of vulnerability and, consequently, its evading political potential. ${ }^{37}$ As disaster risk is probabilistically determined as a function of hazards, ${ }^{38}$ exposure, ${ }^{39}$ and vulnerability to those hazards; vulnerability needs to be quantified, measured. For this purpose, the United Nations Office for Disaster Risk Reduction (UNDRR) has defined vulnerability as 'conditions determined by physical, social, economic and environmental factors or processes which increase the susceptibility of an individual, a community, assets or systems to the impacts of hazards'40 Physical vulnerability involves 'what in the built environment is physically at risk of being affected' ${ }^{41}$ The analysis

33 Mc Gregor (n 3o) 39o.

34 Jessica Mercer et al, 'Framework for integrating indigenous and scientific knowledge for disaster risk reduction' (2009) 34/1 Disasters 219.

35 Inuit Circumpolar Council, 'Indigenous Knowledge (Inuit Circumpolar Council) <https:// www.inuitcircumpolar.com/icc-activities/environment-sustainable-development/ indigenous-knowledge/>.

$36 \quad$ Ibid.

37 This process is common to other areas of international law. The United Nations Committee on Economic, Social and Cultural Rights, for instance, does not refer to poverty or to the impact of colonialism in the development of strong institutional mechanisms when articulating the notion of vulnerability. See O'Donnell (n 29) 12.

38 Hazard is defined by the United Nations Office for Disaster Risk Reduction as 'a process, phenomenon or human activity that may cause loss of life, injury or other health impacts, property damage, social and economic disruption or environmental degradation'. See: UNDRR, Terminology, <https://www.undrr.org/terminology/hazard >.

39 Exposure has been defined as 'the situation of people, infrastructure, housing, production capacities and other tangible human assets located in hazard-prone areas' See: UNDRR, Terminology <https://www.undrr.org/terminology/exposure>. UNGA, Report of the open-ended intergovernmental expert working group on indicators and terminology relating to disaster risk reduction, (1 December 2016) UN Doc A/71/644, 21.

41 Damon P. Coppola, Introduction to international disaster management (ButterworthHeinemann 2011) 148. 
of the physical profile of an area involves the study of its natural makeup (climate, soil type, water resources), the interactions between people and the land (land use, zoning and building regulations, critical infrastructure components) and how people move throughout time (population concentration). ${ }^{42}$ The measurement of economic vulnerability takes into account the economic resources available to protect from the effects of disasters. ${ }^{43}$ Not only the financial conditions of a country, but also that of communities and individuals are assessed. Needless to say, that, from this perspective, subsistence livelihoods characterise a high degree of vulnerability. Environmental vulnerability requires us to look at 'the health and welfare of the natural environment within the area of study that either contributes to or reduces the propensity of the affected population to incur the consequences of disasters. ${ }^{44}$ Social factors of vulnerability encompass 'levels of literacy and education, health infrastructure, the existence of peace and security, access to basic human rights, systems of good governance, social equity, traditional values, customs and ideological beliefs and overall collective organizational systems.45

As a result of the efforts to create taxonomies of conditions or indicators of frailty, Gaillard suggests that our interpretation of disasters continue to be dictated by the constraints of a 'social scientific tradition in the West which fragments reality and which promotes a type of functional analysis that is profoundly ahistorical'.46 Politics, the role of power relations or institutional failures are all absent from the current definition of vulnerability and the taxonomy created by the UNDRR. ${ }^{47}$ In addition to that, the current understanding of vulnerability reflects a static perception of reality, providing for, at most, a linear and minimal consideration of the causes of a disaster. Historical and contextual complexities of indigenous experiences are, therefore, largely overlooked.

In this context, the consequences of colonization and our paradigm of development to indigenous people's ways of life are left out of the discussions concerning vulnerability for the purpose of DRR. There seems to be little, if

\footnotetext{
$42 \quad$ Ibid, $149-151$.

43 Ibid.

44 Ibid.

45 N/ISDR, On Better Terms: A Glance at Key Climate Change and Disaster Risk Reduction Concepts (United Nations, 2006) 11.

$46 \quad$ See Gaillard $\left(\mathrm{n}_{5}\right) 8$.

47 D. Alexander Wisner, 'Vulnerability' in K Penuel et all (eds) Encyclopaedia of Crisis Management (Sage 2013) 980.
} 
any, space to perceive the increase in shipping in the Arctic and the offshore exploitation of oil as political choices. These developments are assumed, they are presented as inevitable consequences of the melting ice. Within this already limited frame, vulnerability is discussed mainly as a function of existing biophysical and sometimes technological risks, such as the behaviour of oil in low temperatures and/or the possible failure of equipment. In this context, scientific expertise and technological solutions continue to be presented as the best options for predicting and preventing threats. ${ }^{48}$

As a result, the scope for the contributions of indigenous peoples to DRR remains limited, as a set of external (scientific) parameters indicates the aspects of their knowledge that are relevant. Traditional knowledge is assessed from and translated into a perspective that differentiates between nature and humans, blurring the significance of traditional knowledge to the identification of hazards and how to cope with them. The centrality of the scientific framework within the AC maintains, if not furthers, indigenous peoples' relational vulnerability. ${ }^{49}$

Without a broader political commitment, which includes a political commitment to learn from and with others, efforts to reduce the risks of oil spills in the Arctic and the potential of the vulnerability paradigm to DRR cannot be fully explored. This commitment requires the due consideration of indigenous groups' ways of living when assessing the potential impact of oil spills. This assessment requires more than the minimisation of the negative effects of shipping and offshore oil exploitation, or the allocation of the opportunities associated with these activities to indigenous groups. It requires the ability to question the inevitability of subjecting indigenous ways of living to the risks of oil spills. In this context, to the extent that international disaster law assumes the risk of oil spills, the vulnerability paradigm brings to the fore the need to consider the situational sources of vulnerability of indigenous peoples as well as their possible actualisation in light of current developments, including the potential opening of new geographical areas for oil exploration, the development and construction of new infrastructure for transporting oil as well as maritime traffic and the risks associated with them.

$48 \quad$ O'Donnell (n 29) 22.

49 Lambert and Scott (n 9) 3. See also Helen C. Wheeler et al, 'The need for transformative changes in the use of Indigenous knowledge along with science for environmental decision-making in the Arctic' (2020) 2 People and Nature, 550. 
Debates concerning oil spills within the EPPR can be traced back to discussions regarding the adequacy of international instruments to protect the environment in the event of a pollution emergency in Arctic waters. In this context, the report 'Analysis of the Adequacy and Effectiveness of Existing Arrangement and Agreements', published in 200o, analysed potential threats and examined the extent to which identified risks were addressed by existing international agreements. ${ }^{50}$ Oil terminals, major oil or hazardous materials transportation routes, exploitation of oil and other mineral resources were among the activities examined. Several countries identified shortcomings in existing agreements and put forward issues that required further attention, such as the need for obligatory navigational corridors and the designation of prohibited sailing areas. ${ }^{51}$ EPPR, nonetheless, deferred the analysis of these issues to the International Maritime Organization (IMO) and concluded that existing international agreements in force appeared 'to address the [...] needs for trans-Arctic cooperation in this field'. ${ }^{2}$

With that choice, EPPR missed an early opportunity to promote the understanding of navigational corridors as a means of avoiding or minimising risks and to highlight the importance of traditional knowledge to their demarcation. Recent discussions concerning navigational corridors suggest that they can ensure that ships travel the safest possible route. ${ }^{53}$ Indigenous communities' suggestion for ships to avoid the Bellot Strait or, at least, to ensure regular contact with the Canadian Coast Guard while in the strait can be seen as an illustration of the potential contribution of their traditional knowledge to the determination of safer routes. ${ }^{54}$ According to Inuit oral history, 'icebergs get sucked in on the east side of Bellot Strait, go underwater, and then stay underwater right through Bellot Strait - and totally out of sight of ship navigators'.55 Recommendations regarding navigational corridors have also been put forward to protect the marine environment. In this regard, it

$50 \quad$ EPPR, Analysis of the Adequacy and Effectiveness of Existing Arrangements and Agreements, $2000<$ https://oaarchive.arctic-council.org/handle/11374/98>.

$51 \quad$ Ibid, 4.

$52 \quad$ Ibid.

53 See the development of Canadian low impact corridors in Jackie Dawnson et al, 'Infusing Inuit and local knowledge into the Low Impact Shipping Corridors: An adaptation to increased shipping activity and climate change in Arctic Canada' (2020) 105 Environmental Science and Policy 19.

$54 \quad$ Ibid, $19-36$.

$55 \quad$ Ibid, 28. 
has been suggested that corridors should avoid areas known to indigenous communities as whale migration routes, whale nurseries and beluga calving as well as bird sanctuaries and seabird colonies. ${ }^{56}$

Despite the deferral of issues related to the demarcation of navigational corridors to the IMO, the risks of oil spills were kept on the AC's agenda. As such, Iceland, in the 2004 Ministerial meeting in Reykjavík, called for the Council's Protection of the Arctic Marine Environment (PAME) working group to 'conduct a comprehensive Arctic marine shipping assessment.' ${ }^{57}$ The assessment was to be carried out under the guidance of Canada, Finland and the United States and 'in collaboration with the Emergency Prevention, Preparedness and Response (EPPR) working group and the Permanent Participants as relevant'.58 According to the assessment, the greatest environmental threat presented by the marine shipping industry was the release of oil into Arctic waters. ${ }^{59}$ Expecting that the surge in tanker transport of oil through Arctic waters would increase the risk of an oil spill, PAME recommended the revision of the analysis of the adequacy of the legal framework existent at that time to address such risk by EPPR. ${ }^{60}$ PAME's assessment also brought up aspects relevant to the definition of navigational corridors: the need to consider Arctic marine use by indigenous communities, and to identify areas of heightened ecological and cultural significance. ${ }^{61}$ Nonetheless, the efforts undertaken to implement these recommendations do not make clear reference to the need to consider the cultural significance of marine areas, continuing to reflect a limited willingness to fully take into account indigenous peoples' ways of living. ${ }^{62}$

A few years later, EPPR published a report on Arctic Emergencies: Current and Future Risks, Mitigation and Response Cooperation. ${ }^{63}$ According to the report, it was unclear whether existing agreements covered the entire Arctic.

\section{$56 \quad$ Ibid, 23 .}

57 Arctic Council. The Reykjavík Declaration. The Fourth Ministerial Meeting of the Arctic Council (24 November 2004).

$5^{8} \quad$ Ibid.

59 Arctic Council, Arctic Marine Shipping Assessment 2009 Report, $7<$ https://pame.is/ images/o3_Projects/AMSA/AMSA_2009_report/AMSA_20o9_Report_2nd_print.pdf >.

6 o Ibid, 6 .

$61 \quad$ Ibid, Recommendations II A and C, 7 .

62 Arctic Council, Status on Implementation of the AMSA 2009 Report Recommendations, (8-9 March 2017) <https://oaarchive.arctic-council.org/bitstream/handle/11374/1957/ PAME_4th-AMSA_Implementation_Progress_Report_for_the_period_2015-2017.pdf >.

63 Arctic Council, Arctic Emergencies: Current and Future Risks, Mitigation and Response Cooperation report (2011) <https://oaarchive.arctic-council.org/bitstream/handle/11374/ 96/Arctic\%2oEmergencies\%2oCurrent\%2oand\%2oFuture\%2oRisks\%2c\%2oMiti gation $\% 2 \mathrm{c} \% 20$ and $\% 20$ Response $\% 20$ Cooperation.pdf?sequence $=1 \&$ isAllowed=y $>$. 
This new insight, together with the lessons learned from the operational difficulties of dealing with the Deepwater Horizon incident in 2010, led EPPR to propose a project to develop an arrangement among the eight Arctic Council States to facilitate the making and acceptance of offers of assistance during an oil spill response operation. ${ }^{64}$ Focusing on response, the report indicated the need to consider the perspective of indigenous groups, not only because they are going to be the first affected, but also because they may 'be among the first responders to emergencies in the Arctic'.65 Affected communities, with their local knowledge and experience have been considered the most efficient workforce as a first response system to oil spills. ${ }^{66}$ Speedy response, even if limited, can reduce harmful consequences of oil spills.

During the Nuuk Ministerial Meeting in 2011, agreement was reached by the Senior Arctic Officials about the establishment of a Task Force to 'develop an international instrument on Arctic marine oil pollution preparedness and response'.67 The Declaration referred to the 'continued engagement of indigenous peoples and communities as a fundamental strength of the Council'.68 The documents that led to the establishment of the Task Force suggest the involvement of Arctic indigenous peoples in the Task Force meetings. In fact, the report of the Task Force regarding the first round of negotiations states that '[a]ll member states, as well as permanent participant Aleut International Association, were present and participated actively at the meeting'69 Interviews conducted by Rise further indicate that Permanent Participants participated in the meetings..$^{70}$ Nonetheless, the scope of their participation remains unclear, as the reports of the Task Force meetings are confidential. ${ }^{71}$ No reference was made by the interviewees to indigenous groups in the composition of the Norwegian, Russian or North-American delegations. ${ }^{72}$

\footnotetext{
$64 \quad$ Ibid, 2.

65 Ibid, 16.

66 Alaska Oil Spill Commission, Report of the Alaska Oil Spill Commission - Executive Summary Spill? The Wreck of the Exxon Valdez (1990) 49.

67 Arctic Council, Nuuk Declaration on the Occasion of the Seventh Ministerial Meeting of the Arctic Council (12 May 2011).

68 Ibid.

69 EPPR, Arctic Council Task Force on Oil Pollution Prevention, Summary two-pager, $5^{\text {th }}$ Meeting, Helsinki (24-25 November 2014).

70 I.H. Rise, 'The Agreement on Cooperation on Marine Oil Pollution Preparedness and Response in the Arctic' (2014) The Arctic University of Norway 57.

71 The fact that MOSPA is an international treaty can constitute a reason for the limited engagement of indigenous groups in its negotiation. See Koivurova and Heinämäki (n 4).

$72 \mathrm{Ibid}$. Even if indigenous groups have integrated other delegations, the lack of reference to their involvement by the interviewees is suggestive of limited contributions.
} 
Representatives from the Government of Nunavut were integrated into the delegation of Canada alongside federal governmental departments with an interest in oil spill response in the Arctic, such as: the Coast Guard, Transport Canada, Environment Canada, and the department on Aboriginal Affairs and Northern Development. ${ }^{73}$ Whilst the involvement of indigenous groups in at least one delegation can be considered a positive starting point, the weight of their views in the Canadian position remains unclear. Within a broader framework, it is important to recall that the centrality of the state in international law has been pointed out as an element that facilitates the political subordination of indigenous groups. ${ }^{74}$

The Task Force concluded its work in 2013. The main objective of the Agreement on Cooperation on Marine Oil Pollution Preparedness and Response in the Arctic (hereinafter MOSPA) is to strengthen 'cooperation and mutual assistance among the Parties on oil pollution preparedness and response in the Arctic in order to protect the marine environment from pollution by oil.: ${ }^{75}$ Despite the reference to preparedness, Rixey points out that the Agreement addresses mainly the aftermath of oil pollution, no regulations for oil exploration or drilling in the Arctic are provided for. ${ }^{76}$ The Agreement has been said to be 'quite traditional and to build upon pollution response in instruments closely modelled on the global International Convention on Oil Pollution Preparedness, Response and Co-operation Convention from 1990' (OPRC). ${ }^{77}$ In this regard, MOSPA has been described as a multilateral implementation agreement under article 10 of the OPRC. ${ }^{78}$

Despite that, Lauta suggests that MOSPA introduced some new legal content to the field of oil response:

It adds emphasis on the vulnerable Arctic environment in the preparedness phase, instates 24-hour contact points, ensures that non-affected member states are notified of pending oil disasters, and initiates an

73 Ibid.

74 Hiroshi Fukurai, 'Fourth World Approaches to International Law (FWAIL) and Asia's Indigenous Struggles and Quests for Recognition under international law' (2018) Asian Journal of Law and Society 227.

75 Arctic Council, Agreement on Cooperation on Marine Oil Pollution Preparedness and Response in the Arctic, Art.1.

76 C.M. Rixey, 'Oil and Sustainability in the Arctic Circle' (2015) 44 Denver Journal of International Law and Policy $45^{2}$.

77 EPPR, Arctic Council SAO plenary meeting 13-14 March 2014, Ruka, Finland, Legal issues related to the Mospa Agreement (2013) ii.

78 Kristian Cedervall Lauta, 'A Drop in the Ocean: Marine Oil Pollution Preparedness and Response in the Arctic' (2014) 5/2 Arctic Review on Law and Politics 244. 
obligation to monitor ongoing spills. Furthermore, it demands the requesting states specify their needs, and institutionalizes a joint review evaluating the efforts. ${ }^{79}$

Some of these new legal provisions seem, nonetheless, to have contributed more to the harmonisation of the law concerning oil spills' response than to its development. The analysis of MOSPA in light of a broader legal framework indicates, for instance, that European Arctic states had already set up a 24-hour contact point and were legally bound to develop a joint review. ${ }^{80}$ Similarly, existing multilateral agreements among Arctic states provided for the duty to monitor oil pollution incidents. ${ }^{81}$ The practical relevance of the obligation to inform all members of the Arctic Council when the severity of an oil pollution incident justifies seems to be reduced in light of the opRC duty to inform the IMO in similar circumstances. ${ }^{82}$ The innovative potential of the provision requiring the specification of the type and the extent of the assistance required also seems limited, as it reflected pre-existing practice. ${ }^{83}$

In this context, the obligation to organise joint exercises and training has been considered the real added value of MOSPA. ${ }^{84}$ Article 13(3) provides that, where appropriate, parties should include stakeholders in the planning and execution of joint exercises and training in opposition to the more limited approach followed in the OPRC, which refers to the training of personnel. Considering that MOSPA's preamble acknowledges not only the risk that marine oil pollution presents to the livelihoods of indigenous communities, but also that indigenous peoples 'can provide valuable resources and knowledge regarding the Arctic marine environment in support of oil pollution preparedness and response', ${ }^{85}$ one could expect the recognition of indigenous peoples as relevant stakeholders. Nonetheless, indigenous communities have not been included in the joint exercises and training until now. Despite that, calls for engaging indigenous peoples in disaster management continue to be broadly emphasized in AC Ministerial meetings. ${ }^{86}$ EPPR has clearly stated that

\footnotetext{
79 Ibid, 244.

8 o Ibid, 241 and 242.

81 Ibid, 242.

$82 \quad$ Ibid.

83 Ibid.

$84 \quad$ Ibid, 243 and 244.

85 Arctic Council, Agreement on Cooperation on Marine Oil Pollution Preparedness and Response in the Arctic (2013) Preamble, para 13.

86 According to Sidorova, 'almost every declaration of the AC emphasized the inclusion and integration of TEK (traditional ecological knowledge) as one its main priorities'. Evgenia
} 
it 'recognizes the importance of involving Arctic inhabitants and seeks their inclusion in its work' 87

There is, therefore, potential to construe the joint exercises as a safe and honest sharing space, in which the exchange of a variety of relevant knowledge to the design of responses to an oil spill in the Arctic could be shared and indigenous communities' needs and concerns put forward. ${ }^{88}$ The recognition of indigenous communities as stakeholders and, consequently, their involvement in the joint exercises can contribute, for instance, to the planning of measures aimed at addressing indigenous activities that might suffer from an oil spill or the mapping of areas that require particular attention in case of an oil spill, be it due to their potential to trap ice or to their ecological and cultural significance. In fact, the legal obligation to include considerations of vulnerable sites and particularly risky activities into national response systems has been provided for in article 4 of MOSPA. ${ }^{89}$

The overall incorporation of traditional knowledge to the development of more recent DRR measures remains limited. The synopsis of the project 'Standardization as a Tool for Prevention of Oil Spills in the Arctic', for instance, indicates that '[s]tandards are developed by professional societies, industry organizations, manufacturing associations, and other national, regional, and international entities and organizations, in response to the needs of their members and stakeholders in any given field.' ${ }^{90}$ The terminology 'stakeholders' is also used to describe the composition of committees that propose

Sirodova, 'The incorporation of Traditional Ecological Knowledge in the Arctic Council: Lip Service?' (2020) Polar Record.

87 EPPR Strategic Plan (approved by SAOs in Fairbanks, March 16,2016), Guiding principle 3.2.

88 This approach is in accordance with the recommendations put forward by the Expert Mechanism on the Rights of Indigenous Peoples. See General Assembly, Promotion and protection of the rights of indigenous peoples in disaster risk reduction, prevention and preparedness initiatives Study by the Expert Mechanism on the Rights of Indigenous Peoples, Annex, (7 August 2014) UN Doc A/HRc/27/66.

89 Article 4 of MOSPA reads: 'Each Party shall maintain a national system for responding promptly and effectively to oil pollution incidents. This system shall take into account particular activities and locales most likely to give rise to or suffer an oil pollution incident and anticipated risks to areas of special ecological significance, and shall include at a minimum a national contingency plan or plans for preparedness and response to oil pollution incidents'.

90 EPPR, Arctic Council SAO Plenary meeting 8-9 March 2017, Juneau, Alaska, USA, Summary Report on Standardization as a Tool for Prevention of Oil Spills in the Arctic <https://oa archive.arctic-council.org/bitstream/handle/11374/2003/EDOCS-4111-v1A-ACSAOUS 204_JUNEAU_2017_3-3-5A_EPPR_Summary_Report_Standards_for_Prevention_final _draft.PDF? sequence $=1$ \& isAllowed $=\mathrm{y}>$. 
specific standards. ${ }^{91}$ As there are not, in principle, reasons to exclude debates concerning the need to adopt standards that take into account economic, environmental and also cultural interests, traditional knowledge could contribute to the design of standards that better reflect the cultural relevance of the environment. Nonetheless, the debates concerning standardisation seem to focus on the notion of physical vulnerability. The determination of whose views are relevant to the management of the risks associated with an oil spill seems, therefore, to be related to the belief that the threats posed by oil pollution can be effectively mitigated through careful planning and effective regulation in areas of high risk. ${ }^{92}$ As a result, the silence towards indigenous groups is followed by EPPR clear recommendations regarding the involvement of technical experts in the promotion of new standards and in the assessment of whether existing and proposed standards meet Arctic challenges. ${ }^{93}$

Drawing attention to the interests of fisheries, which are often at the level of subsistence livelihoods for local communities, Johannsdottir and Cook point out that the power imbalance between them and companies working in oil extraction has prioritised the engagement of industry groups and associations in the standardisation project. ${ }^{94}$ In fact, the interaction between EPPR and industry has been seen as a means of advancing EPPR's mandate, as both 'share a responsibility and have a common interest in safety, search and rescue, and environmental effects. ${ }^{95}$ Within this broader context, the exclusion of concerns related to different ways of living might not only silence possible conflicting interests, but also reiterate the overall marginalisation of indigenous groups. An opportunity to learn from the experiences of other indigenous communities is also lost. In this regard, the efforts of the Inupiat in northern Alaska to pursue higher standards and increase the accountability of offshore exploration developments is an important one. ${ }^{96}$

As part of the attempts to mitigate the effects of an oil spill in the Arctic, EPPR has also looked at disaster response. In this context, it was considered necessary to pay greater attention to the training of Arctic communities. This was done through the project 'Prevention, Preparedness and Response in Small

\footnotetext{
$91 \quad$ Ibid.

92 Det norske Veritas, Recommended Practices for Arctic Oil Spill Prevention (EPPR) (Narayana Press) 35 .

93 Ibid.

94 Lara Johannsdottir and David Cook, 'Systemic risk of maritime-related oil spills viewed from and Arctic and insurance perspective' (2019) 17 Ocean and Coastal Management 5.

95 EPPR Strategic Plan (approved by SAOs in Fairbanks, March 16,2016), Guiding principle 3.3.

96 Inuit Circumpolar Council, The Sea Ice Never Stops: Circumpolar Inuit Reflections on Sea Ice Use and Shipping in Inuit Nunaat (December 2014) 47.
} 
Communities', in which community leaders and local emergency response officials with responsibility for oil spill preparedness in small communities were surveyed. ${ }^{97}$ The survey was utilised to measure their preparedness in face of risks related to oil spills. The results indicated that roughly $25 \%$ of small communities are prepared relative to risk; $50 \%$ are moderately prepared; and $5 \%$ are less than adequately prepared. ${ }^{98}$ These findings identified the need for greater risk awareness and local level preparedness, as well as access to information about best practices. ${ }^{99}$ When considering these aspects, traditional knowledge can, once more, be relevant, as its due consideration facilitates an effective framing of messages regarding the risks of oil spills. For this purpose, the messages might need to take into account the values and concerns of the relevant communities as well as culturally appropriate methods of transmission of information. The consideration of traditional knowledge might also bring into question the scope of the response measures, as culturally appropriate measures might be required to address the impact of the oil spill. In this regard, Lambert and Scott suggest the need to take into account indigenous spiritual healing systems and medical practices. ${ }^{100}$

As part of the overall objective of limiting the spread of oil and minimising the impacts of any spill, early intervention requires an initial assessment of the benefits and consequences of response strategies and techniques. ${ }^{101}$ The assessment has to consider, for instance, whether response actions would cause more secondary damage (the degradation of permafrost or disturbance of the tundra vegetation) than leaving the oil to weather naturally. An informed decision, in these contexts, requires, among others, significant knowledge of the affected ecosystems. Nonetheless, little is known from a scientific perspective about Arctic ecosystems. ${ }^{102}$

In this context, the contribution of indigenous peoples to the development of capacities to efficiently respond to oil spills lies exactly in their comprehensive

97 EPPR. Arctic Council SAO Plenary meeting 22-23 Marc 2018, Levi, Finland, Oil Spill Preparedness in Small Communities <https://oaarchive.arctic-council.org/bitstream/ handle/11374/2143/SAOFI2O2_2018_LEVI_InfoDoc13_EPPR-Oil-Spill-Preparedness-in -Small-Communities-Observers.pdf?sequence $=1 \&$ \&isAllowed $=y>$. Inuit communities have stated that they do not have the capacity to deal with a large pollution response. Inuit Circumpolar Council (n 96) iii.

$98 \quad$ Ibid.

$99 \quad$ Ibid.

100 Lambert and $\operatorname{Scott}(\mathrm{n} 9)$.

101 E.H. Owens et al, EPPR, Field Guide for Oil Spill Response in Arctic Waters (Arctic Council Secretariat 2017) 2-10.

102 Jeffrey Short and Susan Murray, 'A frozen hell' (13 April 2011) 472 Nature <https://www .nature.com/articles/472162a >. 
knowledge of the environment and the interactions within. Traditional knowledge can contribute to the understanding of ocean currents in a specific area as well as ice convergence in certain places helping to identify the directions in which oil could move once trapped in ice floes. Traditional knowledge regarding how marine mammals move might also be relevant to determine the areas that need to be prioritised by response efforts to allow these animals to breathe through ice holes without becoming contaminated.

Analysis of DRR efforts undertaken by the EPPR suggests the adoption of a limited approach to risk assessment, one that does not take into account indigenous ways of living and perceiving the world. For instance, the risks of an oil spill to traditional knowledge have not been clearly thematized and, therefore, no measures are directed at limiting the vulnerability of indigenous communities in relation to this risk. Nonetheless, the contamination of animals due to an oil spill might deter traditional hunting and gathering and, with that, imperil the transmission of traditional knowledge. ${ }^{103}$ With that, not only food security and the sociocultural value of eating and sharing traditional foods are compromised, but also the ability of younger generations to develop their skills to locate dangerous areas on the ice, identify precursors to hazardous conditions and cope with hazard encounters is also imperilled. ${ }^{104}$ The engagement with indigenous communities and their knowledge in DRR is important not only for a more comprehensive assessment of risks already mapped, but also for the identification of risks that are particular to their way of living and perceiving the world.

Within the AC, it is important to note that other AC working groups might have been more open to engaging with indigenous groups and to incorporate traditional knowledge to their projects. ${ }^{105}$ Some of the risks faced by indigenous communities might have been considered by other working groups. Nonetheless, this approach reiterates the fragmentation of knowledge, limiting the development of a systemic approach to DRR. In this regard, the involvement of indigenous and other Arctic inhabitants in emergency prevention, preparedness and response continues to be of critical importance. ${ }^{106}$

\footnotetext{
103 Ibid.

104 James D. Ford et al, 'Climate Change and Hazards Associated with Ice Use in Northern Canada' (2008) Arctic, Antarctic and Alpine Research: An interdisciplinary Journal, 656.

105 Sidorova identified four trends in the incorporation of traditional knowledge in the AC. The first encompasses attempts to study knowledge co-production; the second, efforts to incorporate traditional knowledge to fulfil formal requirements of studies and projects; the third, studies that claimed to incorporate traditional knowledge and the four, projects led by Permanent Members in collaboration with the working groups. Sidorova (n 86).

106 EPPR Strategic Plan (approved by SAOs in Fairbanks, March 16, 2016), Guiding principle 3.2.
} 
Used adjectivally in English, 'vulnerable' refers to a subject or situation that finds its own defence difficult. Such disadvantage carries overtones of weakness and dependency. ${ }^{107}$ The notion of vulnerability within DRR embraces the idea of susceptibility to being wounded and harmed. Its political potential highlights the fact that this susceptibility has been and continues to be construed. In fact, the current use of the notion of vulnerability within policy making, by positioning certain groups, including indigenous groups, under a scientific gaze to measure their vulnerability, is by itself contributing to such a construction. Scientific measurements and assessments determine what needs to be known, from what perspective and, to a certain degree, who is entitled to act on those outcomes.

Another trend of the notion of vulnerability is the identification of vulnerable individuals as victims. Arctic indigenous peoples pictured 'as embodiments and harbingers of what climate change has in store for the rest of the world, 108 seem to adequately fit the notion of a victim. In fact, this characterisation has been politically used by themselves, when stating that ' $\mathrm{h}] \mathrm{ere}$ we are, Inuit of the world who have lived in harmony with our surroundings, [...] being bombarded by toxins.'109 One could even say that they have sought the acknowledgement of their status as victims through legal claims. In 2005, the Inuit, under auspices of the Inuit Circumpolar Council, submitted a petition to the Inter-American Commission of Human Rights claiming that the United States had violated the human rights of the Inuit (to life, food, and culture, inter alia) by refraining from action to decrease $\mathrm{CO}_{2}$ emissions. Recently, a similar step has been taken by the Arctic Athabascan Council, which accused Canada of violating Athabascan rights due to air pollution, including black carbon, which is considered another important driver of Arctic climate change due to its effect on snow/ice. In this process, the use of the term 'victim' could bring legal benefits to some of the communities affected, especially in the case of human rights violations leading to compensation and reparation orders. More broadly, the term victim allows us to pin down who are the victims and the cause of victimisation, questioning the extent to which an allencompassing understanding of humanity embraced by the Anthropocene is adequate.

\footnotetext{
107 O'Donnell (n 29) 3.

108 Marybeth Long Martello, 'Arctic Indigenous Peoples as Representations and Representatives of Climate Change' (2008) 38 Social Studies of Science 354

109 Ibid, 368.
} 
This reflection becomes essential when DRR continues to differentiate between humans and the value of their knowledge. If the consideration of the views of indigenous groups continues to rely on their recognised relevance by scientists, traditional knowledge risks being continually instrumentalised, leading to the maintenance of current systems, relations, and practices, instead of enabling the emergence of new ways of being and dwelling that might prove more inclusive, just, and compassionate. The instrumentalisation of traditional knowledge reiterates a history of marginalisation and oppression, which impedes a mutual understanding of its cultural, material, and epistemological basis.

The analysis of the extent to which indigenous groups have been able to contribute to the work of EPPR seems to illustrate the effects of such marginalisation. The impact of oil spills on indigenous groups as well as the relevance of their traditional knowledge are acknowledged, nonetheless their voices are not heard, their knowledge not incorporated in DRR. Indications that indigenous peoples have participated in the meetings of EPPR are not followed by the discussion of the views expressed and the extent to which they contributed to the studies and adopted policies. The limited involvement of indigenous people means a limited ability to identify risks to a particular way of living and perceiving the world and, therefore, reduce disaster risk.

To ensure the relevance of DRR initiatives, the consideration of indigenous traditional knowledge requires the creation of a relationship of mutuality, in which different ways of living and understanding the world are equally respected. Spaces for the development of such relationships do exist. The AC can, itself, be considered such a space as a soft law organisation. More specifically, the joint exercises carried on within the MOSPA framework can also provide such space. In fact, every new EPPR project regarding oil spills provides an opportunity to move towards a more comprehensive understanding of the risks that such spills present, one that considers different ways of living and equally values them.

It is acknowledged that the participation of indigenous groups in these spaces does not automatically lead to the incorporation of their views in DRR. As such, this can be considered an initial step in the development of DRR initiatives that are meaningful to indigenous communities and address their needs. A step that can lead to the development of new methodological approaches and, consequently, new relationships between scientific and traditional knowledge. We might, for instance, need to consider whether the characteristics of traditional knowledge, the fact that it is cumulative and dynamic, adaptive, and ancestral, and is produced in a collective process, require an 
effort of epistemic reconstitution of our world and our understanding of risks and vulnerability. Such an effort might require the opening of DRR to multiple conceptions of time and spiritual connections with nature. In this process, input from indigenous communities will be particularly relevant. Nonetheless, even before more challenging methodological and epistemological issues are raised, an initial openness to traditional knowledge might bring to the fore the fact that not only oil spills, but also climate change can be considered as a risk within international disaster law, opening the space for a long-term understanding of vulnerability.

The contextualization of risk and a better understanding of vulnerability also bring to the fore the need to consider whose voices should be taken into account. In this context, Permanent Participants are aware of their different levels of participation. They have tried to address such discrepancies through the amendment of the Indigenous Peoples' Secretariat (IPS) Terms of Reference and Procedural Guidelines. ${ }^{110}$ Nonetheless, even if successful, this attempt does not consider different levels of engagement among those that are represented by a particular Permanent Participant nor the indigenous communities that are not represented by a Permanent Participant. The extent to which indigenous communities are impacted by a given extractive development or shipping and the risks therein differ. As such, the analysis of the situational vulnerability of these communities requires a more specific analysis of the risks each one of them faces. This analysis also needs to take place on a continuous basis, as shipping traffic might change, and the long-term environmental changes are difficult to predict.

110 Indigenous Peoples Secretariat, Arctic Council Member States and Permanent Participants. Memorandum of Understanding Discussion Points. DRAFT (2009). 